\title{
ЗЕМЕЛЬНІ ВІДНОСИНИ ЯК ОБ'ЄКТ КРИМІНАЛЬНО-ПРАВОВОЇ ОХОРОНИ
}

\section{Сингаєвська М. I.}

У науковій статmі проаналізовано земельні відносини як об'єкт кримінально-правової охорони. Розкрито поняття «земельних відносин» як основного термінологічного звороту під час здійснення юридичного аналізу злочинів у сфері земельних відносин. Розглянуто класифікацію кримінальних правопорушень у сфері земельних відносин за об'єктом злочину з поділом їх на чотири групи, яка вказує на характерні особливості земельних відносин як об'єкт злочину.

Ключові слова: об'єкт кримінально-правової охорони, земельні відносини, злочини у сфері земельних відносин, об'єкт злочину, класифікація злочинів за об'єктом, земельні злочини.

В научной статье проанализированы земельных отношений как объект уголовно-правовой охраны. Раскрыто понятие «земельных отношений» как основного терминологического оборота при осуществлении юридического анализа преступлений в сфере земельных отношений. Рассмотрена классификация уголовных преступлений в сфере земельных отношений объектом преступления с разделом их на четыре группы, что указывает на характерные особенности земельных отношений как объект преступления.

Ключевые слова: объект уголовно-правовой охраны, земельные отношения, преступления в сфере земельных отношений, объект преступления, классификация преступлений по объекту, земельные преступления.

Singaevska M. I. Land relations as an object of criminal protection

The article is devoted to the analysis of land relations as object of criminal law protection and the peculiarities of establishing criminal liability for crimes in this area. The concept of "land relations" (public relations regarding the possession, use and disposal of (and) as the main terminological turnover in the legal analysis of crimes in the field of land relations is revealed. Taking into account the diversity of the theory of object of crime, the classification of criminal offenses in the field of land relations by object of crime with their division into four groups, which indicates the characteristics of land relations as object of crime, as the dispositions of articles responsibilities in this area are usually blanket. It is indicated that the correctly and clearly written composition of the criminal offense will allow law enforcement officers to accurately qualify the actions of persons in committing crimes in this area. It is established that in all cases when it comes to offenses in the field of land relations there is no understanding of when and what actions are criminally punishable, and which entail other types of liability. It is noted that most scholars have limited the definition of crimes in this category too narrowly. At the same time, it is established that the recognition of the object of criminal offenses in the field of land relations, land law established by land legislation, land ownership as real estate, permanent use, lease rights allows to refer to the investigated category of offenses not only criminal offenses, provided for in Section VIII of the Special Part "Criminal Offenses against the Environment", but also to expand the category of crimes in the field of land relations by other sections of the Criminal Code of Ukraine - "Criminal Offenses in the Sphere of Official Activity and Professional Activity in Public Services computers (computers), systems and computer networks and telecommunications networks", "Criminal offenses against property".

Key words: object of criminal law protection, land relations, crimes in the field of land relations, object of crime, classification of crimes by object, land crimes.

Постановка проблеми та її актуальність. Відповідно до статей 13 та 14 Конституції України земля є об'єктом права власності українського народу та $є$ основним національним багатством, що перебуває під особливою охороною держави [1].

Відповідно «земля» як об'єкт охорони держави має надзвичайно важливе значення, хоча б тому, що кількість її не збільшується, а відкриття ринку землі, без належного врегулювання та налагодження схеми відповідальності за вчинені кримінальні правопорушення, може призвести до збільшення кількості злочинів у цій сфері та спричинення збитків державним інтересам.

Історично склалось, що земельні відносини в Україні та їх охорона є особливо актуальними, зважаючи на специфіку місця знаходження нашої держави на найбільш родючих землях Європи. Захист виробника, інвестора, збереження фондів як-то лісових, водних, пайових, є важливими завданнями правоохоронної системи, зловжи-

(c) Сингаєвська М. І., 2020 
вання та вчинення правопорушень у цих сферах завдають непоправну шкоду природі, а також матеріальну шкоду в особливо великих розмірах державі, створює негативне амплуа та дискредитує їі на міжнародному рівні.

Важливим $\epsilon$ той факт, що під час учинення злочинів у сфері земельних відносин суб'єкти цих правопорушень зазвичай $\epsilon$ освіченим особами, спеціалістами в галузі права та у сфері земельного законодавства, а, відповідно, правильно та чітко виписаний склад кримінального правопорушення дозволить працівникам правоохоронних органів точно кваліфікувати дії осіб під час учинення злочинів у цій сфері.

Суттєвим є правильне розуміння специфіки вчинення кримінальних правопорушень у цій сфері, їх тісне поєднання в різних складах злочинів, що на практиці створює певні складнощі у кваліфікації дій підозрюваних, а це, зі свого боку, призводить до винесення виправдувальних вироків у судах.

Ураховуючи, що кримінальна відповідальність за посягання у сфері земельних відносин передбачена низкою статей Кримінального кодексу України - самовільне зайняття земельної ділянки та самовільне будівництво (стаття 197-1), забруднення або псування земель (стаття 239); незаконне заволодіння ґрунтовим покривом (поверхневим шаром) земель (стаття 239-1); незаконне заволодіння землями водного фонду в особливо великих розмірах (стаття 239-2); умисне знищення або пошкодження територій, взятих під охорону держави, та об'єктів природно-заповідного фонду (стаття 252); безгосподарське використання земель (стаття 254), - особливої уваги потребує визначення об'єкта цих кримінальних правопорушень, а саме, встановлення які суспільні відносини є безпосереднім об'єктом під час посягання у сфері земельних відносин і чи завжди водночас заподіюватиметься шкода відносинам у сфері довкілля.

Крім того, потрібно враховувати, що дії службових осіб під час учинення злочинів, пов'язаних із незаконним переходом права власності на земельні ділянки як-от пайового, лісового, водного фонду, тощо до іншої фізичної особи кваліфікуються за нормами статей Особливої частини Кримінального кодексу України: зловживання владою або службовим становищем (стаття 364), службове підроблення (стаття 366), службова недбалість (стаття 367), прийняття пропозиції, обіцянки або одержання неправомірної вигоди службовою особою (стаття 368), зловживання впливом (369-2).
Аналіз останніх досліджень і публікацій. Земельні відносини як об'єкт неправомірного посягання досліджені в науковій літературі досить широко, зоглядунаїхактуальність. Нимизаймались такі провідні вчені, як Аверянов В., Антонюк Н., Баранівський В., Вишнівський І., Дрозд О., Єропкіна М., Єрофєєва Б., Ізовіта А., Мірошниченко О., Мовчан Р., Олійник О., Панов М., Саркісова Т., Шульга А., та інші.

Метою статті $\epsilon$ висвітлення особливостей визначення земельних відносин як об'єкта кримінально-правової охорони задля окреслення шляхів конкретизації та підвищення ефективності протидії кримінальним правопорушенням у цій сфері.

Виклад основного матеріалу. 3 метою визначення характерних особливостей земельних відносин як об'єкта кримінально-правової охорони для початку розглянемо окремо поняття «земельних відносин» та «об'єкта злочину».

Відповідно до ст. 2 Земельного кодексу України земельні відносини - це суспільні відносини щодо володіння, користування й розпорядження землею. Об'єктами земельних відносин є землі в межах території України, земельні ділянки та права на них, зокрема на земельні частки (паї) [2].

Земля стає предметом земельних відносин у зв'язку із привласненням іï продуктів і використанням іï корисних властивостей. Водночас вона залишається об'єктом природи. Особливості земельних відносин полягають у тому, що ïх виникнення й розвиток безпосередньо пов'язані з об'єктивними закономірностями розвитку людського суспільства й суспільного виробництва [3, с. 4].

Статтею 211 Земельного кодексу України передбачений перелік земельних правопорушень, за які настає юридична відповідальність. Така відповідальність може бути цивільною, адміністративною або кримінальною. Зі свого боку, кримінальна відповідальність за порушення у сфері земельних відносин настає в разі наявності ознак складу відповідного кримінального правопорушення, передбаченого Кримінальним кодексом України.

Особливе місце у правовій охороні земельних ресурсів посідає забезпечення права земельної власності на земельні ділянки громадян, юридичних осіб та держави, що виділені на місцевості в натурі [4, с. 188].

За своєю юридичною природою земельні правопорушення належать до так званого «складного типу» правопорушень, зважаючи на їх 

та науково-методичне забезпечення

подвійну правову природи. Оскільки протиправність земельних правопорушень визначається як земельним законодавством, так і адміністративним, кримінальним, цивільним тощо [5, с. 133].

Доходимо висновку, що в усіх випадках, коли йдеться про правопорушення у сфері земельних відносин, наштовхуємось на нерозуміння того, коли саме та які дії в цьому разі $є$ кримінальнокараними, а які спричинюють інші види відповідальності.

Виникає закономірне питання, що ж таке «земельне правопорушення», та які особливі ознаки відрізняють його від інших правопорушень, коли саме воно стає злочином та за яких умов.

Аналіз юридичної літератури дозволяє виділити декілька видів класифікацій злочинів у сфері земельних відносин. Проте не всі вони є вичерпними та такими, що охоплюють найбільш актуальну на сьогодні сферу ринкового обігу землі. Найбільш точним, на думку Ізовіта А., за результатом аналізу визначено класифікацію, зроблену за об'єктом злочину [6, с. 140].

Загальновизнано, що об'єктом злочину завжди виступає те благо, якому злочином завдається реальна шкода чи створюється загроза заподіяння такої шкоди. В науці кримінального права найбільш визнаною $є$ погляд, згідно з яким об'єктом будьякого злочину $\epsilon$ охоронювані законом про кримінальну відповідальність суспільні відносини [7].

До такого визначення об'єкта злочину науковці прийшли не одразу та продовжують дискутувати із цього приводу. Такі видатні вчені, як Нікіфоров Б., Глістін В., Коржанський М., Тацій В., поділяють думку, за якою об'єкт злочину - це суспільні відносини, які охороняються кримінальним законом, унаслідок порушення яких спричиняється соціально-небезпечна шкода. Об'єкт злочину це мішень, по якій б'є кожний злочин. Там, де немає посягання на суспільні відносини, де шляхом зміни суспільних відносин не спричинюється шкода, немає злочину [8, с. 26].

Водночас деякі вчені, серед яких професор Наумов А., висловлюють думку про те, що теорія об'єкта злочину як суспільних відносин «спрацьовує» не завжди i, отже, не може бути визнана універсальної теорією [9, с. 91-92].

Перш ніж дати визначення об'єкта злочину, необхідно зауважити, що більшість іноземних «криміналістів» як більш раннього, так і сучасного періоду розглядають об'єкт у двох площинах. По-перше, як нормативну, правову категорію, адже злочин насамперед порушує норму, кримінально-правову заборону. По-друге, злочин посягає на благо, що охороняється цією нормою («правове благо»), й заподіює йому шкоду. Причому під таким благом розуміють як матеріальні, так і нематеріальні, але цілком реальні й конкретні явища життя, інтереси [10, с. 23].

Загалом, варто погодитись із думкою Чигарина В. щодо місця об'єкта злочину в системі структури злочину та його важливості під час кваліфікації кримінально правопорушення, оскільки «немає злочину без об'єкта посягання. Без об'єкта злочину немає і складу злочину. Чотиричленна структура складу злочину (об'єкт, суб'єкт, об'єктивна сторона, суб'єктивна сторона) вимагає під час кваліфікації діяння першочергового встановлення об'єкта посягання - того, чому цим діянням заподіяно або може бути заподіяна шкода, необхідна для визначення діяння злочином. За відсутності конкретного адресата посягання у вигляді певної соціально значущої цінності, що охороняється кримінальним законом, не може йтись про склад будь-якого злочину» [11].

Дискусії серед науковців розгорнулись щодо того, які саме злочини потрібно віднести до вчинених у сфері земельних відносин. Так, Чабанна $€$. та Данилова Є. земельні злочини поділяють на: злочини у сфері обігу землі - це злочини, які посягають на землю як на об'єкт нерухомості, та злочини у сфері землекористування - це злочини, що посягають на землю як на об'єкт екології, довкілля та природний ресурс [12, с. 24].

Шульга А. дійшов висновків, що «земельними злочинами» в контексті Особливої частини КК України варто визначати суспільно небезпечні, винні (умисні) діяння (дію або бездіяльність), передбачені відповідними статтями VIII Розділу Особливої частини, які вчиняються відповідним суб'єктом злочину й посягають на суспільні відносини у сфері охорони, раціонального використання та відтворення земельних ресурсів» [4, с. 194].

На думку Єрофеєва Б., всі склади злочинів, пов'язаних із земельними відносинами, можуть бути поділені на два види:

1) спеціальні злочини, об'єктом яких є безпосередньо земельні відносини;

2) загальні, об'єктом яких поряд з іншими суспільними відносинами можуть бути й земельні відносини [13, с. 417].

У підручнику «Земельне право України» за редакцією Погрібного О. наведено класифікацію зазначених злочинів із поділом їх на чотири групи:

1) злочини, які мають екологічний характер;

2) злочини економічного характеру; 
3) злочини, що посягають на землю як на об'єкт державного управління;

4) злочини, котрі безпосередньо відносяться до того, що вирощується на землі [13, с. 418].

Об'єктом злочину, що має екологічний характер, $\epsilon$ земля як об'єкт екосистеми (спеціальні склади - забруднення або псування земель (ст. 239 КК); порушення правил охорони надр (ст. 240); безгосподарське використання земель (ст. 254); загальні склади - порушення правил екологічної безпеки (ст. 236); невжиття заходів щодо ліквідації наслідків екологічного забруднення (ст. 237); приховування або перекручення відомостей про екологічний стан або захворюваність населення (ст. 238); проєктування чи експлуатація споруд без систем захисту довкілля (ст. 253) тощо).

Об'єктом злочину економічного характеру $\epsilon$ земля як майновий об'єкт (загальні склади умисне знищення або пошкодження майна (ст. 194); необережне знищення або пошкодження майна (ст. 196) тощо).

Злочини, які посягають на землю як на об'єкт державного управління, - це самовільне захоплення земельної ділянки (ст. 197-1 КК України).

До злочинів, що безпосередньо стосуються того, що вирощується на землі, належать знищення або пошкодження лісових масивів (ст. 245), незаконна порубка лісу (ст. 246), тощо.

Дозволимо собі не погодитись із такими вузьким визначенням цього виду злочинів, а також із тим, що вони обмежені виключно VIII Розділом Особливої частини Кримінального кодексу України, а саме «Злочинами проти довкілля».

Практика розгляду справ цієї категорії у своїй повсякденній роботі, а також статистична вибірка з Єдиного реєстру досудових розслідувань дозволяє впевнено стверджувати, що протягом останніх трьох років додаткова відмітка щодо кваліфікації «110 - вчинення злочинів у сфері земельних відносин» та «111 - інші правопорушення у сфері земельних відносин» найчастіше застосовується до злочинів, передбачених Розділом XVII Кримінального кодексу України «Кримінальні правопорушення у сфері службової діяльності та професійної діяльності з надання публічних послуг», а протягом 2018-2020 років, крім цього, також до Розділу XVI Кримінального кодексу «Кримінальні правопорушення у сфері використання електронно-обчислювальних машин (комп'ютерів), систем та комп'ютерних мереж і мереж електрозв'язку», а саме ст. 362 КК України несанкціоновані дії з інформацією, яка оброблюється в елек- тронно-обчислювальних машинах (комп'ютерах), автоматизованих системах, комп'ютерних мережах або зберігається на носіях такої інформації, вчинені особою, яка має право доступу до неї. Почастішали випадки кваліфікації дій винних осіб за ст. 190 Кримінального кодексу України - шахрайство.

Завдяки вдосконаленню земельного законодавства, більш чітко розмежовано повноваження посадових осіб органів Держгеокадастру, кадастрових реєстраторів, сертифікованих інженерів землевпорядників, нотаріусів, тобто суб'єктів, які найчастіше вчиняють злочини у сфері земельних відносин.

Таким чином, відслідковується тенденція, за якою «земля» цікавить злочинців саме як об'єкт нерухомості більше ніж як об'єкт екології, довкілля та природний ресурс.

Відповідно, автор схиляється до думки, вже висловленої Панкратовим І. та підтриманої Саркісовою Т., щодо виділення загального та конкретного об'єкта земельного правопорушення, де загальний об'єкт - земельний правопорядок, установлений земельним законодавством, як конкретний об'єкта виступає земля, конкретна земельна ділянка, права власників, володільців, користувачів та орендаторів землі [5, с. 133].

Саме зазначений розподіл на об'єкти найбільш точно, на нашу думку, вказує на характерні особливості земельних відносин як об'єкта злочину, оскільки диспозиції статей, що передбачають відповідальність у цій сфері, зазвичай є бланкетними.

Під час застосуванні бланкетних диспозицій зміст кримінально-правового діяння визначається як законом про кримінальну відповідальність, так і нормами інших галузей права. Останні не замінюють норми кримінального права. Вони виконують у таких випадках «субсидіарну», конкретизуючу функцію. Вони уточнюють і доповнюють положення закону про кримінальну відповідальність, але і за бланкетної диспозиції така норма не змінюється за своєю суттю. Це зумовлено тим, що за умови порушення норм інших галузей права завжди наявна «кримінально-правова компонента», наприклад, спеціальні ознаки, вказані в диспозиціях статей КК (суспільно небезпечні наслідки чи спосіб, місце, час, обстановка вчинення злочину). Тим самим законодавець за допомогою використання норм інших галузей лише уточнює в кожному разі склад кримінального правопорушення, котрий хоча й багато в чому базується на нормах інших галузей права, але не втра- 

та науково-методичне забезпечення

чає свого особистого (кримінально-правового) і спеціального змісту й форми. [14, с. 30].

Висновки. Здійсненний аналіз особливостей земельних відносин як об'єкта кримінально-правової охорони дає можливість упевнено сказати, що більшість науковців занадто вузько обмежило злочини цієї категорії виключно злочинами, передбаченими Розділом VIII Особливої частини Кримінального кодексу України, притому що об'єктом таких посягань виступає земельний правопорядок, встановлений земельним законодавством, право власності на землю, як об'єкт нерухомості, право постійного користування, право оренди. Це дозволяє розширити категорію злочинів у сфері земельних відносин іншими розділами Кримінального кодексу України: «Кримінальні правопорушення у сфері службової діяльності та професійної діяльності з надання публічних послуг», «Кримінальні правопорушення у сфері використання електронно-обчислювальних машин (комп'ютерів), систем та комп'ютерних мереж і мереж електрозв’язку», «Кримінальні правопорушення проти власності».

\section{Література}

1. Конституція України від 28 червня 1996 p. URL: https://zakon.rada.gov.ua/laws/ show/254\%D0\%BA/96-\%D0\%B2\%D1\%80\#Text (дата звернення: 30.07.2020).

2. Земельний кодекс України від 25.10.2001 № 2768-III. URL: http: / /zakon.rada.gov.ua/ laws/show/2768-14 (дата звернення: 03.08.2020).

3. Шульга М. Земельне право України. Підручник. Харків : Право, 2013. 520 с.

4. Шульга А. Особливості об'єктного складу земельних злочинів. Вісник кримінологічної асоціації України. № 1. 2015. С.186-199.

5. Саркісова Т. Підходи до розуміння земельного правопорушення. Науковий вісник Херсон- ського державного університету. № 1. Том. 2. 2015. C. 132-135.

6. Ізовіта А. Кримінологічна характеристика злочинів, що вчиняються на земельному ринку. Актуальні проблеми держави та права: збірник наукових праць. Вип. 60. Одеса: Юридична література, 2011. С. 139-145.

7. Бажанов М. Кримінальне право України. Електронна бібліотека Pravo.biz.ua. : юрид. б-ка. URL: http://pravoznavec.com.ua/books/25/28/\#chlist (дата звернення: 13.08.2020).

8. Коржанский Н. Объект преступления и предмет уголовно-правовой охраны. Москва, 1980. 246 с.

9. Курс российского уголовного права. Общая часть / под ред. В. Кудрявцева, А. Наумова. Москва, 2001. 767 c.

10. Гавриш С. Теоретические предпосылки исследования объекта преступлений. Право и политика. № 11. 2000. С. 4-15.

11. Чигарин Т. Объект преступления и его структура. Pravo.biz.ua : юрид. б-ка. URL: http:// pravoznavec.com.ua/books/35/28/\#chlist (дата звернення: 13.08.2020).

12. Чабанная Е., Данилова Е. Преступления в сфере оборота земли. Российский следователь. 2007. № 2. C. 24-26.

13. Каракаша І.І. Земельне право України. Підручник / за ред. О. Погрібного Київ : Істина, 2003. $448 \mathrm{c}$.

14. Квасневська Н. Проблема кваліфікації злочинів при бланкетній диспозиції закону про кримінальну відповідальність. Правові засади підвищення ефективності боротьби зі злочинністю в Україні: матеріали наукової конф. (15 травня 2008 року). Харків. Право. 2008. С. 28-32.

Сингаєвська М. І., ад’юнкт кафедри кримінального права Національної академії внутрішніх справ 